Cell Research (2002); 12(1):55-62

http://www.cell-research.com

\title{
Effects of cisplatin on telomerase activity and telomere length in BEL-7404 human hepatoma cells
}

\author{
Ru Gang ZHANG, Ru Ping ZHANG, Xing Wang WANG, Hong XIE* \\ Department of Biotherapy, Institute of Biochemistry and Cell Biology, Shanghai Institutes for Biological Sciences, \\ the Chinese Academy of Sciences, Shanghai 200031, China
}

\begin{abstract}
Telomerase activity was inhibited in a dose and time-dependent manner with the treatment of cisplatin for 24,48 , or $72 \mathrm{~h}$ in a concentration ranged from 0.8 to $50 \mu \mathrm{M}$ in BEL-7404 human hepatoma cells. There were no changes in expression pattern of three telomerase subunits, its catalytic reverse transcriptase subunit (hTERT), its RNA component (hTR) or the associated protein subunit (TP1), after cisplatin treated for $72 \mathrm{~h}$ with indicated concentrations. Mean telomere lengths were decreased by the cisplatin treatment. Cell growth inhibition and cell cycle accumulation in $\mathrm{G}_{2} / \mathrm{M}$ phase were found to be correlated with telomerase inhibition in the present study, but percentages of cell apoptosis did not change markedly during the process.
\end{abstract}

Key words: Telomerase, telomere, cisplatin, hepatocellular carcinoma, cell cycle, cell growth.

\section{INTRODUCTION}

Primary hepatocellular carcinoma (PHCC), one of the most common malignancies in the world, is an aggressive cancer. The mean survival time from establishment of diagnosis is only about 4 months ( 2 months if the diagnosis is made late). It causes about 250,000 deaths annually[1]. Therefore, PHCC with a high fatality rate and short disease period has been one of the major health problems in the world.

Up to now, chemotherapy is one of the most efficient strategies in PHCC treatment, especially for unsectable patients. Cisplatin is a key chemotherapy agent in the treatment of PHCC, binding directly to DNA[2]. It has been suggested that cisplatin is activated intracellularly by the generation of a positively alkylating activity and inhibits DNA synthesis by altering the DNA template[3].

Telomeres, the tandam repeats of DNA, form the

*Corresponding author: Prof. Hong XIE

Tel: 0086-021-64735606; Fax: 0086-021-34010138;

E-mail: xiehong@sunm.shcnc.ac.cn

Received Nov-8-2001 Revised Jan-16-2002 Accepted Jan-18-2002 end of eukaryotic chromosome, comprising a G-rich strand and a complementary C-rich strand. The sequence of a repeating unit of human telomeres is 5'TTAGGG-3'. Telomeric DNA shorten about 50-200 bp per doubling in normal human cells[4]. Human telomerase is a ribonucleoprotein complex, composed of a catalytic reverse transcriptase subunit (hTERT), an RNA component (hTR) that serves as a template for the synthesis of telomeric repeats, and an associated protein subunit (TP1)[5-7]. It adds telomeric repeats to the 3 ' end of telomeric DNA. This telomere stabilization by telomerase can lead to unlimited cell proliferation.

It was reported that $\mathrm{PHCC}$ exhibited a high incidence of telomerase activity and that telomerase activity increased in accordance with degree of histological undifferentiaton of PHCC but was absent in normal liver tissue[8],[9]. However, the nship between the treatment efficiency of cisplatin and telomerase activity in PHCC has not yet been elucidated. Here, we investigated the effects of cisplatin on the telomerase activity and telomere 
length in BEL-7404 human hepatoma cells.

\section{MATERIALS AND METHODS}

\section{Cell and culture condition}

BEL-7404 human hepatoma cell line cells from Cell Bank of Chinese Academy of Sciences[10], were cultured in RPMI-1640 medium (Gibco) supplemented with $10 \%$ heat-inactivated newborn calf serum, at $37^{\circ} \mathrm{Cin}$ a humidified $\mathrm{CO}_{2}$ incubator containing $5 \% \mathrm{CO}_{2}$ and $95 \%$ air.

\section{Drug}

Cisplatin (Sigma) was dissolved in RPMI-1640 to the final concentration of $5 \mathrm{~m} \mathrm{M}$ and stored at $4^{\circ} \mathrm{C}$.

\section{Assessment of cell proliferation}

MTT assay was conducted to determine the cell proliferation [11]. Cells were seeded at $1 \times 10^{4}$ cells /well in a 96-well plate and incubated overnight. The drug was added to the final concentration ranged from $0.8 \mathrm{mM}$ to $50 \mathrm{mM}$ and treated for 24,48 or $72 \mathrm{~h}$. Following culture, the cells were incubated with $800 \mathrm{mg} / \mathrm{L} \mathrm{3-}-(4,5-$ dimethylthiazol-2-yl)-2, 5-diphenyltetrazolium bromide (MTT, Sigma). Four hours later, 10\% sodium dodecyl sulphate- 5\% isobutanol- $0.12 \%$ hydrochloric acid solution was added to solubilize the formazan product. The plate was then incubated at $37^{\circ} \mathrm{C}$ for another $12 \mathrm{~h}$. The absorbance at $570 \mathrm{~nm}$ was measured with a model 550 microplate reader (Bio-Rad). Percentage of cell growth inhibition was expressed as: $(\mathrm{A}-\mathrm{B}) / \mathrm{A} \times 100 \%$, where $\mathrm{A}$ was the absorbance value from control cells and $\mathrm{B}$ was the absorbance value from experimental cells.

\section{Telomerase assay}

Telomerase activity was assayed using PCR-based telomeric $r$ epeat amplification protocol (TRAP) assay as previously describe $\mathrm{d}[12]$. Cells were collected and washed with PBS, lysed in $1 \times 3-[(3$ -cholamidopropyl)dimethylammonio]-1-propanesulfonic acid (C HAPS, Sigma) buffer, incubated on ice for $30 \mathrm{~min}$, and centrifu ged at $12,000 \times \mathrm{g}$ for $30 \mathrm{~min}$. The protein concentration was deter mined by Coomassie Protein Assay. Each of TRAP reactions con tained $1 \mathrm{mg}$ of total protein. The reaction mixture [20 mM Tris-H $\mathrm{Cl}$ (pH 8.3), $1.5 \mathrm{mM} \mathrm{MgCl}_{2}, 63 \mathrm{mM} \mathrm{KCl}, 0.005 \%$ Tween-20, $1 \mu \mathrm{M}$ EGTA, $50 \mu \mathrm{M}$ of each dNTPs and $0.1 \mu \mathrm{g}$ TS (5'- AATCCGTCG AGCAGAGTT-3')] was incubated at $30^{\circ} \mathrm{C}$ for $30 \mathrm{~min}$, heated at 9 $4^{\circ} \mathrm{C}$ for $5 \mathrm{~min}$. Then $0.1 \mathrm{mg}$ of return primer ACX [5'- GCGCGG (CTTACC)3CTAACC -3'], $0.1 \mu \mathrm{g}$ of internal control primer NT (5'- ATCGCTTCTCGGCCTTTT -3'), 0.01 aM of internal contro 1 template TSNT (5'-AATCCGTCGAGCAGAGTTAAAAGGCC GAGAAGCGAT -3') and 2 units Taq DNA polymerase (Promeg a) were added. The reaction mixture was then subjected to $28 \mathrm{PC}$ R cycles: $94^{\circ} \mathrm{C}$ for $30 \mathrm{~s}$ and $60{ }^{\circ} \mathrm{C}$ for $30 \mathrm{~s}$. PCR products were sepa rated by electrophoresis on $12 \%$ nondenaturing polyacrylamide $\mathrm{g}$ els and stained with SYBR Green I (FMC) for $15 \mathrm{~min}$, visualized a nd analyzed by UVP system. In every experiment, a negative con trol (1 CHAPS lysis buffer) was included. All of experiments wer e repeated at least twice.

The relative telomerase activity was quantified by the formula:
$\mathrm{TP}=[(\mathrm{A} / \mathrm{B}) /(\mathrm{A}$ cell control $/ \mathrm{B}$ cell control $)] \times 100$

Where $\mathrm{TP}=$ total product, $\mathrm{A}=$ total intensity of telomerase product ( $50 \mathrm{bp}, 56 \mathrm{bp}, 62 \mathrm{bp} . .$. ), and $\mathrm{B}=$ intensity of internal control (36 bp).

\section{RT-PCR}

Total cellular RNA was extracted from cells using Trizol (Life Technologies, Inc.) according to the instructions of the manufacturer. In each reaction, $1 \mathrm{mg}$ of total RNA was reverse transcribed into cDNA using M-Mlv reverse transcriptase (Promega). Primer sets used to amplify specific sequences were

5'-CGGAAGAGTGTCTGGAGCAA-3' and

5'- GGATGAAGCGGAGTCGGA -3' for hTERT;

5'- TCTAACCCTAACTGAGAAGGGCGTAG -3' and

5'- GTTTGCTCTAGAATGAACGGTGGAAG -3' for hTR;

5'-TCAAGCCAAACCTGAATCTGAG -3' and

5'-CCCGAGTGAATCTTTCTACGC-3' for TP1;

5'- GTGGGGCGCCCCAGGCACCA -3' and

5'- GTCCTTAATGTCACGCACGATTTC -3' for $\beta$-actin. The PCR conditions of hTERT and TP1 were $94^{\circ} \mathrm{C}, 45 \mathrm{~s} ; 60^{\circ} \mathrm{C}, 45 \mathrm{~s} ; 72^{\circ} \mathrm{C}$, 90 s for 31 and 29 cycles, respectively. And the PCR conditions of hTR and b-actin were $94^{\circ} \mathrm{C}, 45 \mathrm{~s} ; 55^{\circ} \mathrm{C}, 45 \mathrm{~s} ; 72^{\circ} \mathrm{C}, 90 \mathrm{~s}$ for 28 and 22 cycles, respectively[5].

\section{Telomere length assay}

Genomic DNA samples were prepared as described[13]. Cells were lysed and proteins were digested in $10 \mathrm{mM}$ Tris- $\mathrm{HCl}$ ( $\mathrm{pH} 8.0$ ), $100 \mathrm{mM} \mathrm{NaCl}, 25 \mathrm{mM}$ EDTA, $0.5 \%$ SDS, $0.1 \mathrm{mg} / \mathrm{ml}$ proteinase $\mathrm{K}$ at $48^{\circ} \mathrm{C}$ overnight. Following two extractions with phenol and one with chloroform, DNA was precipitated with ethanol and dissolved in $10 \mathrm{mM}$ Tris- $\mathrm{HCl}$ (pH 8.0) and $1 \mathrm{mM}$ EDTA (TE). Telomere length was detected using TeloTAGGG telomere length assay (Roche) according to the manufacturer' s protocol. For each sample, $1 \mathrm{mg}$ of genomic DNA was digested with Rsa I/Hinf I (Sigma), separated on a $0.8 \%$ agarose gel, transferred to a nylon membrane (Amersham Hybond- $\mathrm{N}^{+}$), and hybridized with a telomere specific digoxigenin (DIG)-labeled probe, incubated with antiDIG-alkaline phosphatase and detected by chemiluminescence. The blotted signal was divided into 30 equidistant intervals from 1.9 to 21.2 kilobases to calculate mean telomere length (terminal restriction fragment, TRF) using the formula TRF $=\sum(\mathrm{ODi}) / \sum$ $(\mathrm{ODi} / \mathrm{Li})$, where ODi was the chemiluminescent signal and $\mathrm{Li}$ was the length of the TRF fragment at position i[14].

\section{Flow cytometry analysis of cell cycle and apoptosis}

The cells were harvested and resuspended in the solution containing $40 \mathrm{mM}$ sodium citrate, $250 \mathrm{mM}$ sucrose and $5 \%$ DMSO. The suspension was stored at $-20^{\circ} \mathrm{C}$ for $20 \mathrm{~min}$, then thawed rapidly at room temperature and centrifuged to collect the cells. The cells were resuspended in a solution containing RNase A ( $5 \times 10^{4}$ unit/g, $50 \mathrm{mg} / \mathrm{L}$ ) and $20 \mathrm{mg} / \mathrm{L}$ propidium iodide (PI). The cell cycle distribution and apoptosis were determined by the fluorescence of individual cells measured by flow cytometry[15]. 


\section{RESULTS}

Effect of cisplatin on telomerase activity

The $\mathrm{IC}_{50}$ concentration of cisplatin was $12.5 \mathrm{mM}$, calculated by growth inhibition of BEL-7404 human hepatoma cells treated with twelve different concentrations of cisplatin for $72 \mathrm{~h}$ (data not showed). Based on this concentration, cisplatin concentrations used in experiments were selected as follows: 50, 25, 12 . 5, 3.5 and $0.8 \mu \mathrm{M}$. Telomerase activity of BEL-7404 human hepatoma cells was inhibited in a dose and time-dependent manner with cisplatin treated for 24,48 or $72 \mathrm{~h}$ in a concentration ranged from 0.8 to $50 \mu \mathrm{M}$ (Fig 1A and Fig 1B). To analyze telomerase inhibition on gene expression level, the expression of three telomerase subunits mRNA, hTERT, hTR and TP1, was assayed after cisplatin treated for 72 $\mathrm{h}$ in a concentration ranged from 0.8 to $50 \mu \mathrm{M}$. Results showed that the expression pattern of these three subunits mRNA did not change with cisplatin treatment (Fig1C).

A
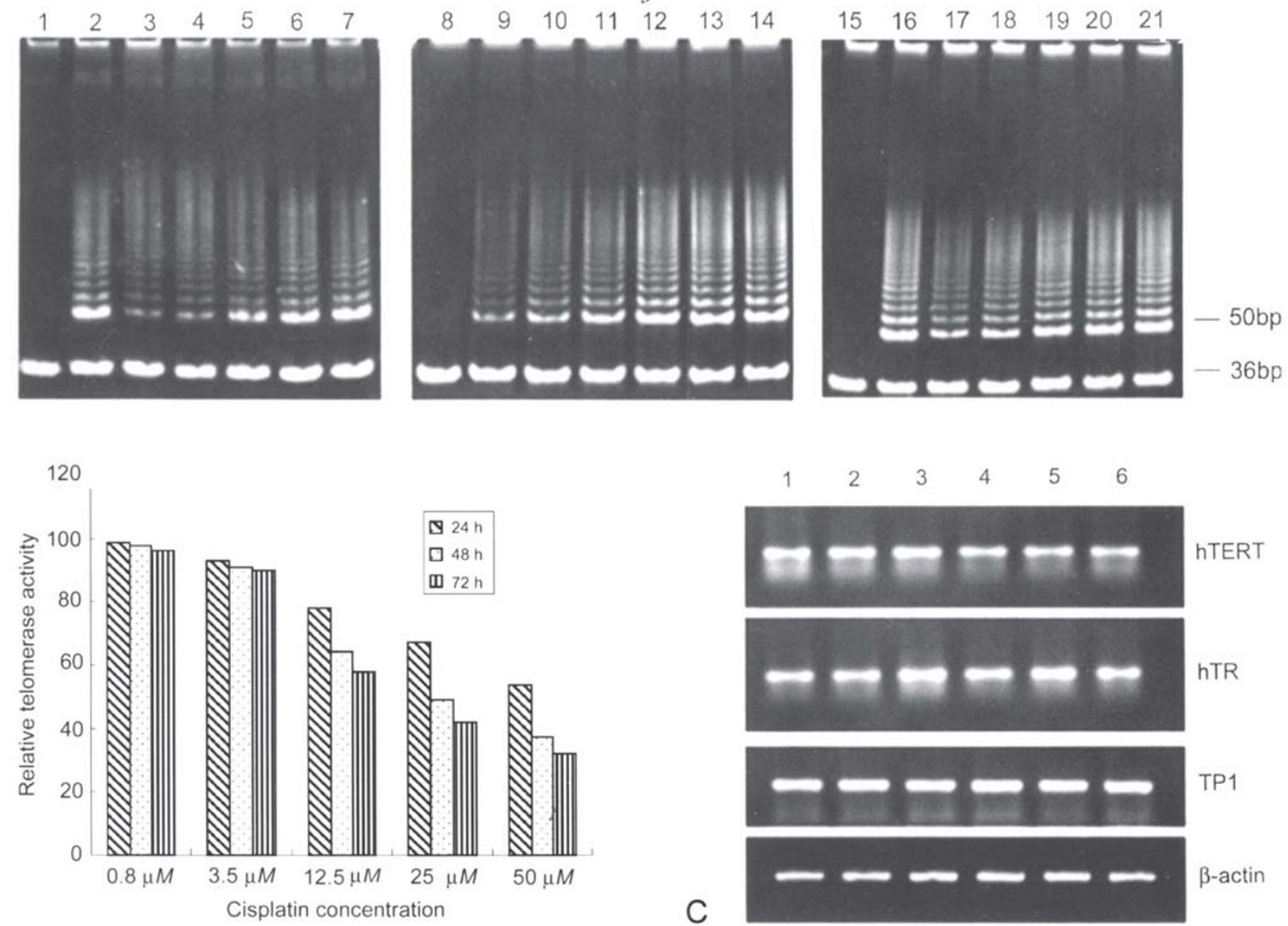

Fig 1. A. Inhibition of telomerase activity by cisplatin in a dose and time-dependent manner in BEL-7404 human hepatoma cells shown by PCR-based telomeric repeat amplification protocol (TRAP) assay. Lane 1, 8, 15: negative control; Lane 2, 14, 16: cell control; Lane 3-7, telomerase activity in presence of cisplatin for $72 \mathrm{~h}(50,25,12.5,3.5$ and $0.8 \mu M)$; Lane 9-13: telomerase activity in presence of cisplatin for $48 \mathrm{~h}(50,25,12.5,3.5$ and $0.8 \mu M)$; Lane 17-21: telomerase activity in presence of cisplatin for $24 \mathrm{~h}(50,25,12.5,3.5$ and $0.8 \mu \mathrm{M})$. All experiments were repeated at least twice and one representative result was shown here. B. Telomerase activity of BEL-7404 human hepatoma cells treated with cisplatin in Fig 1a was converted to the relative value. C. RT-PCR analysis of hTERT, hTR and TP1 mRNA expression with cisplatin treatment for $72 \mathrm{~h}$ in concentrations from 0.8 to 50 . Lane 1, cell control; Lane 2, $50 \mu M$; Lane 3, $25 \mu M$; Lane 4, 12.5 $\mu M$; Lane 5, 3.5 $\mu M$; Lane 6, 0.8 $\mu \mathrm{M}$. b-actin was used as standard. Amplified sequences for hTERT, hTR, TP1 and b-actin are 146, 126, 264 and $539 \mathrm{bp}$, respectively. 
Telomerase inhibition and telomere shortening by cisplatin

Effect of cisplatin on mean telomere length

Mean telomere length of BEL-7404 human

ment for 24,48 , or $72 \mathrm{~h}$ in a concentration ranging from 0.8 to $50 \mu \mathrm{M}$. However, telomere shortening in hepatoma cells was decreased by the cisplatin treat-

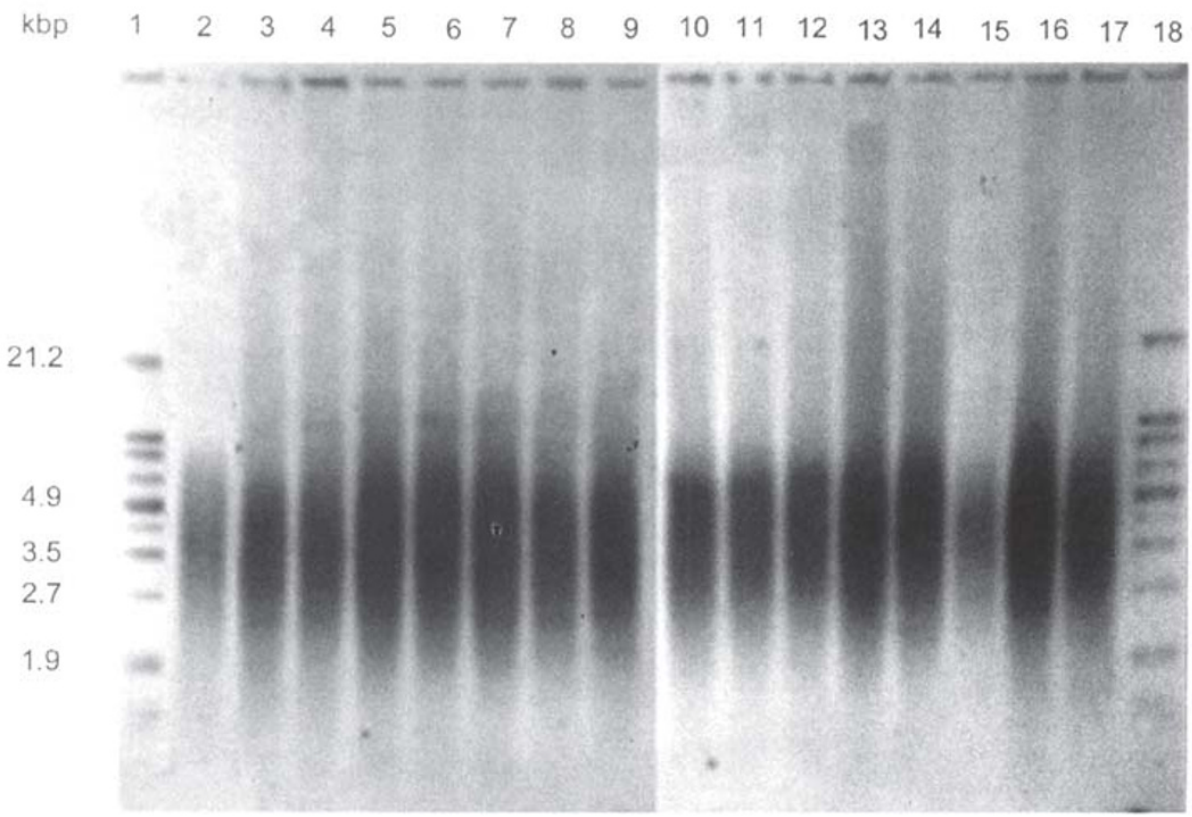

Mean telomere length in each lane

\begin{tabular}{|c|c|c|c|c|c|c|c|c|c|c|c|c|c|c|c|c|}
\hline No. of Experiment & 2 & 3 & 4 & 5 & 6 & 7 & 8 & 9 & 10 & 11 & 12 & 13 & 14 & 15 & 16 & 17 \\
\hline 1 & 4.2 & 3.2 & 3.5 & 3.6 & 3.8 & 3.6 & 3.5 & 3.6 & 3.5 & 3.7 & 3.7 & 3.8 & 4.0 & 4.0 & 4.2 & 4.1 \\
\hline 2 & 4.2 & 3.1 & 3.4 & 3.6 & 3.9 & 3.9 & 3.4 & 3.6 & 3.4 & 3.8 & 3.7 & 3.8 & 4.1 & 4.0 & 4.1 & 4.0 \\
\hline
\end{tabular}

Fig 2. The upper part indicates the shortening of mean telomere length (terminal restriction fragments, TRF) in cisplatin treated BEL-7404 human hepatoma cells by telomere length assay. Lane 1 and 18, molecular marker; Lane 2, cell control; Lane 3-7, cisplatin treated for $72 \mathrm{~h}(50,25,12.5,3.5$, and $0.8 \mu M)$; Lane 8-12: cisplatin treated for 48 h (50, 25 , 12.5, 3.5, and 0.8 $\mu M)$; Lane 13-17: cisplatin treated for $24 \mathrm{~h}(50,25,12.5,3.5$, and $0.8 \mu M)$. The lower part indicates the calculated value of mean telomere length in each lane from two typical experiments. Values shown in experiment 1 reflect the result shown in the upper part figure.
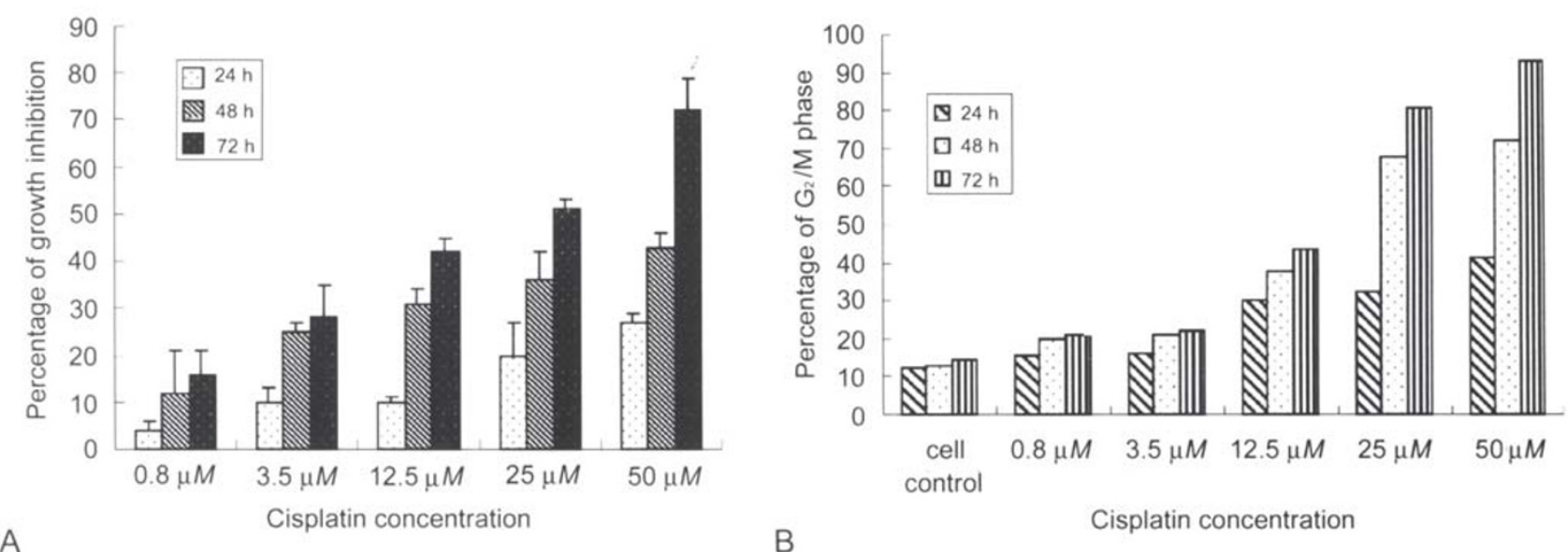

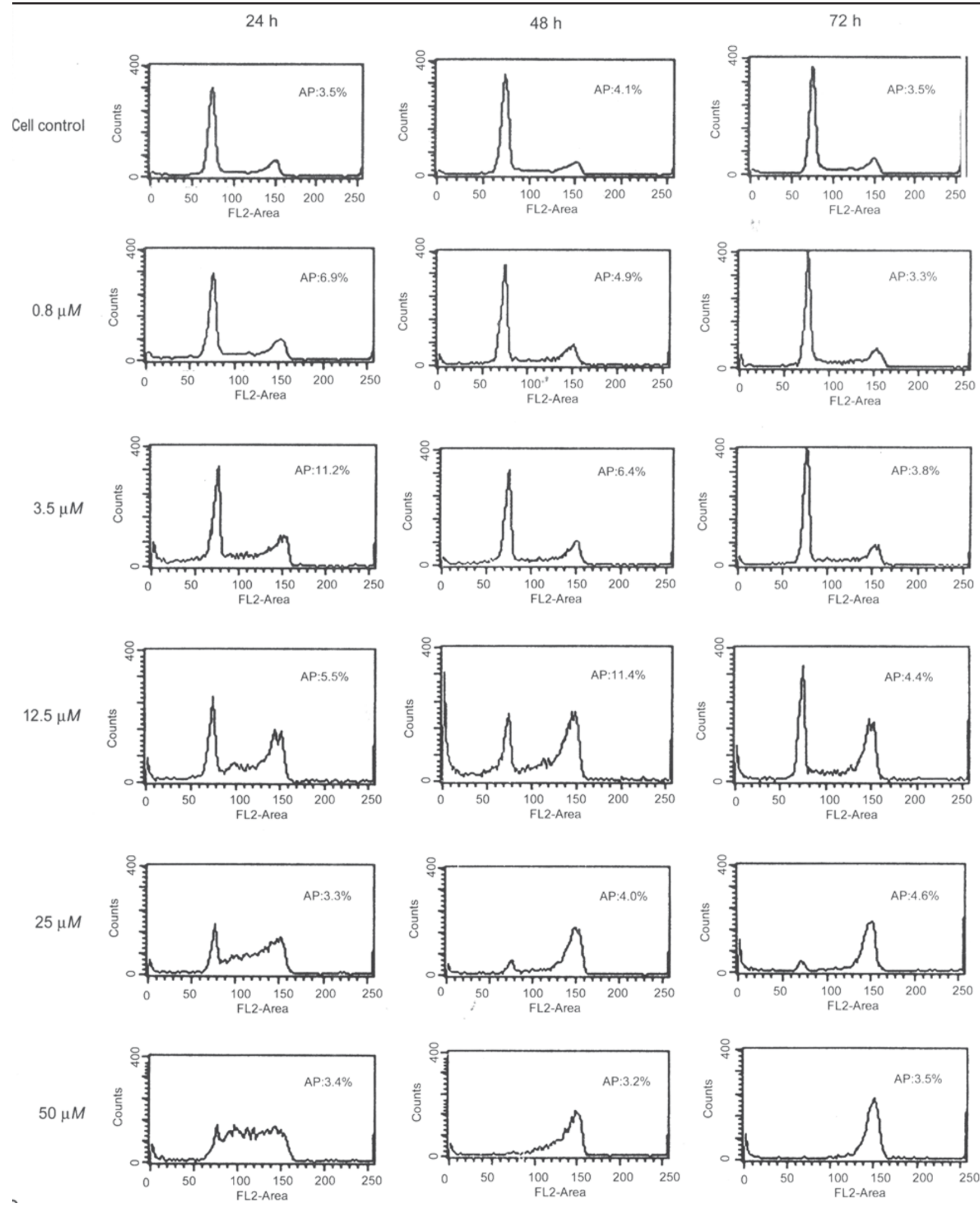

Fig 3. (A and B, at the bottom of p58) A. Growth inhibition of BEL-7404 human hepatoma cells treated with cisplatin by MTT assay. Each value represents mean \pm SD from triplicate wells. B. Cell cycle distribution in cisplatin treated BEL-7404 human hepatoma cells. Cell cycle arrested at $\mathrm{G}_{2} / \mathrm{M}$ phase with the treatment of cisplatin in a dose and time dependent manner. C. Cell apoptosis in cisplatin treated BEL-7404 human hepatoma cells. Histograms of DNA contents of untreated cell control and treated with $0.8,3.5,12.5,25$ and $50 \mu M$ are shown. Cells were maintained in the presence of cisplatin for 24,48 , and $72 \mathrm{~h}$ without a change in medium and collected at the times indicated. AP means the percent of apoptosis. 
cisplatin treated cells was independent of time or dose in the present study. The shortened mean telomere length ranged from 3.1 to $4.1 \mathrm{Kbp}$ compared with $4.2 \mathrm{Kbp}$ of cell control. The telomere length assay was repeated four times and the results of all experiments showed the same pattern of telomere shortening. Results of two typical experiments were showed here (Fig 2).

\section{Effects of cisplatin on cell growth and cell cycle} distribution

Cell growth and cell cycle distribution during cisplatin treatment were investigated to correlate these effects with telomerase inhibition or telomere shortening. Cell growth was inhibited in a dose and time-dependent manner by cisplatin treatment with indicated time and concentration, analyzed by MTT assay (Fig 3A). After cisplatin exposure, the cell cycle of treated cells was arrested at $\mathrm{G}_{2} / \mathrm{M}$ phase (Fig 3B). The percentages of cell apoptosis in general did not change markedly during the treatment (Fig 3C), despite a few points showing increased apoptosis, but repeated experiments showed that the increased points were random, indicating that it might be due to experimental error.

\section{DISCUSSION}

Cisplatin causes DNA strand breaks especially at guanine residues. Burger et al showed that cisplatin reduced telomerase activity in testicular tumor cells for the first time[16]. However, the opposite observation was presented by $\mathrm{Ku}$ et al who found no effect of cisplatin on telomerase activity in nasopharyngeal cancer cells[17]. Recently, Akeshima et al reported similar result as $\mathrm{Ku}$ et al in ovarian cancer cells[18]. In the present study, we found telomerase activity inhibition by cisplatin in BEL-7404 human hepatoma cells. We assume that telomerase inhibition by cisplatin may be cell type specific.

Burger et al suggested that telomerase inhibition by cisplatin was the results of its effects on gene transcription based on decreasing in hTR expression in testicular tumor cells[16]. But Akeshima et al demonstrated that hTERT expression did not change with time after cisplatin treatment in ovarian cancer cells[18], and Lin et al reported the increasing in hTERT mRNA and protein during cisplatin treatment[19]. Here, we found no changes in expression level of hTR, hTERT or TP1 mRNA in BEL-7404 human hepatoma cells during cisplatin treatment. Abundant evidences indicate that the regulation of telomerase is multifactorial in mammalian cells and involves telomerase gene expression, post-translational protein to protein interactions, and protein phosphorylation[20]. We assume that telomerase activity is inhibited by cisplatin via indirect pathway based on the present study.

Telomere loss by cisplatin treatment was reported for the first time in Hela cells which had very long telomere (about $20 \mathrm{Kbp}$ ) by Ishibashi et al[21]. The formation of intrastrand G-Pt-G adducts was suggested to account for the shortening of telomere. In this study, we showed the decrease of telomere in BEL-7404 human hepatoma cells which telomeres were very short in comparison with normal cells or other cancer cells (e.g. Hela cells), and this shortening of telomere may be more effective in destroying of telomere function.

Many reports showed that telomerase activity was associated with cell growth[22]. Recently, telomerase activity inhibited by cisplatin was found correlated with cell growth inhibition by Faraoni et al and Terashima et al[23],[3]. Our observation also confirmed above reports.

Telomerase inhibition was found to correlate with cell cycle accumulation in $\mathrm{G}_{2} / \mathrm{M}$ phase in SW480 colon carcinoma cells by doxorubicin treatment[24]. However, later reports revealed that telomerase inhibition was correlated with the increase of cell death instead of $\mathrm{G}_{2} / \mathrm{M}$ phase cell cycle accumulation[25]. Here, through flow cytometry, we found in comparison with cell control, cell apoptosis did not increase markedly in treated cells while cell cycle significantly accumulated in $\mathrm{G}_{2} / \mathrm{M}$ phase. Results of electromicroscopy also confirmed the above observation (data not shown). Our previous study also showed that inhibition of telomerase activity by telomerase RNA component antisense oligonucleotide arrested cell cycle at $\mathrm{G}_{2} / \mathrm{M}$ phase in BEL-7404 human hepatoma cells[26]. Based on the above observation, we deduce that telomerase inhibition is correlated with cell cycle accumulation in G2/M phase but not with cell apoptosis increasing. Our other 
study by using doxorubicin in BEL-7404 human hepatoma cells also showed the same relationship between telomerase inhibition and G2/M phase cell cycle accumulation.(data not shown)

Previously, Ishibashi et al demostrated that telomere loss correlated with cell apoptosis induction in Hela cells[21]. But present study found no correlation between shortening of telomere and induction of apoptosis. In our previous study, we found that apoptosis was induced in BEL-7404 human hepatoma cells when mean telomere length decreased to about $1.7 \mathrm{Kbp}$ [27]. In present investigation, mean telomere length did not reach to such critical length, consistent with our previous observation that apoptosis was not induced by cisplatin in BEL-7404 human hepatoma cells with indicated treatment.

In conclusion, in BEL-7404 human hepatoma cells, telomerase activity was inhibited by cisplatin in a dose and time-dependent manner, and mean telomere length was decreased by the treatment. Cell growth inhibition and cell cycle accumulation in G2/ $\mathrm{M}$ phase were found to be correlated with above effects during the treatment. The present study indicates that telomerase inhibition and telomere shortening by cisplatin may contribute to its possible mechanisms in efficiency of the treatment for PHCC.

\section{REFERENCES}

[1] Colleoni M, Gaion F, Liessi G, et al. Medical treatment of hepatocellular carcinoma: any progress? Tumori 1994; 80:315-26.

[2] Han, R. Primary hepatocellular carcinoma, pp591-592, In Chemoprevention and drug therapy of cancer. Peking: Peking Medical University Press; 1991.

[3] Kiyozuka Y, Yamamoto D, Yang J, et al. Correlation of chemosensitivity to anticancer drugs and telomere length , telomerase activity and telomerase RNA expression in human ovarian cancer cells. Anticancer Research 2000; 20:203-12.

[4] Zhang RG, Yuan JH, Xie H. Telomerase and tumor. Chinese Journal of Cell Biology 2000; 22:25-7.

[5] Nakamura TM, Morin GB, Chapman KB, et al. Telomerase catalytic subunit homologs from fission yeast and human. Science 1997; 277:955-9.

[6] Feng J, Funk WD, Wang SS, et al. The RNA component of human telomerase. Science 1995; 269:1236-41.

[7] Harrington L, McPhail T, Mar V, et al. A mammalian telomerase-associated protein. Science 1997; 275:973-7.

[8] Tahara H, Nakanishi T, Kitamoto M, et al. Telomerase activity in human liver tissues: comparison between chronic liver disease and hepatocellular carcinomas. Cancer Research 1995; 55:2734-6.

[9] Nakashio R, Kitamoto M, Tahara H, et al. Significance of telomerase activity in the diagnosis of small differentiated hepatocellular carcinoma. International Journal of Cancer 1997; 74:141-7.

[10] Chen R, Zhu D, Te X, et al. Establishment of three human liver carcinoma cell lines and some of their biological characteristics in vitro. Science Sinica 1980; 23:23647.

[11] Wang XW, Zhang RG, Xie H. Combined effect of alphafetoprotein antisense oligodeoxynucleotide and 5-fluorouracil on human hepatoma cell growth. Chinese Medical Journal 1999; 112:743-6.

[12] Zhang RG, Wang XW, Yuan JH, et al. Using a nonradioisotopic, quantitative TRAP-based method detecting telomerase activities in human hepatoma cells. Cell Research 2000; 10:71-7.

[13] Counter CM, Avilion AA, Lefeuvre CE, et al. Telomere shortening associated with chromosome instability is arrested in immortal cells which express telomerase activity. EMBO Journal 1992; 11:1921-9.

[14] Ulaner GA, Hu JF, Vu TH, et al. Tissue-specific alternate splicing of human telomerase reverse transcriptase (hTERT) influences telomere lengths during human development. International Journal of Cancer 2001; 91: 644-9.

[15] Andreassen PR, Margolis RL. Microtubule dependency of P34cdc2 inactivation and mitotic exit in mammalian cells. Journal of Cell Biology 1994; 127:789-802.

[16] Burger AM, Double JA, Newell DR. Inhibition of telomerase activity by cisplatin in human testicular cancer cells. European Journal of Cancer 1997; 33:638-44.

[17] Ku WC, Cheng AJ, Wang TCV. Inhibition of telomerase activity by $\mathrm{PKC}$ inhibitors in human nasopharyngeal cancer cells in culture. Biochemical and Biophysical Research Communication 1997; 241:730-6.

[18] Akeshima A, Kigawa J, Takahashi M, et al. Telomerase activity and p53- dependent apoptosis in ovarian cancer cells. British Journal of Cancer 2001; 84:1551-5.

[19] Lin Z, Lim S, Viani MA, et al. Down-regulation of telomerase activity in malignant lymphomas by radiation and chemotherapeutic agents. American Journal Pathology 2001; 159:711-9.

[20] Liu JP. Studies of the molecular mechanisms in the regulation of telomerase activity. FASEB Journal 1999; 13:2091-104.

[21] Ishibashi T, Lippard SJ. Telomere loss in cells treated with cisplatin. Proceeding of National Academy of Sciences USA 1998; 95:4219-23.

[22] Greider CW. Telomerase activity, cell proliferation, and cancer. Proceeding of National Academy of Sciences USA 1998; 95:90-2.

[23] Faraoni I, Turriziani M, Masci G, et al. Decline in telomerase activity as measure of tumor cell killing by antineoplastic agents in vitro. Clinical Cancer Research 1997; 3:579-85.

[24] Zhu X, Kumar R, Mandal M, et al. Cell cycle-dependent modulation of telomerase activity in tumor cells. Proceeding of National Academy of Sciences USA 1996; 93: 6091-5.

[25] Holt SE, Aisner DL, Shay JW, et al. Lack of cell cycle regulation of telomerase activity in human cells. Pro- 
Telomerase inhibition and telomere shortening by cisplatin

ceeding of National Academy of Sciences USA 1997; 94: 10687-92.

[26] Zhang RG, Wang XW, Yuan JH, et al. Human hepatoma cell telomerase activity inhibition and cell cycle modulation by its RNA component antisense oligodeoxyribonucleotides. Acta Pharmcologia Sinica 2000; 21:673-8.

[27] Zhang RG, Wang XW, Guo LX, et al. Growth inhibition of BEL-7404 human hepatoma cells by expression of mutant telomerase reverse transcriptase. International Journal of Cancer 2002; 97:173-9. 